Article

\title{
Impact of Climate Change on Natural Snow Reliability, Snowmaking Capacities, and Wind Conditions of Ski Resorts in Northeast Turkey: A Dynamical Downscaling Approach
}

\author{
Osman Cenk Demiroglu ${ }^{1,2,3, *}$, Mustafa Tufan Turp ${ }^{3,4}$, Tugba Ozturk ${ }^{3,5}$ and \\ Mehmet Levent Kurnaz ${ }^{3,6}$ \\ 1 Department of Tourism and Hotel Management, Istanbul Bilgi University, Istanbul 34060, Turkey \\ 2 Department of Tourism Administration, Bogazici University, Istanbul 34342, Turkey \\ 3 Center for Climate Change and Policy Studies, Bogazici University, Istanbul 34342, Turkey; \\ tufan.turp@boun.edu.tr (M.T.T.); tugba.ozturk@isikun.edu.tr (T.O.); levent.kurnaz@boun.edu.tr (M.L.K.) \\ 4 Institute of Environmental Sciences, Bogazici University, Istanbul 34342, Turkey \\ 5 Department of Physics, Isik University, Istanbul 34980, Turkey \\ 6 Department of Physics, Bogazici University, Istanbul 34342, Turkey \\ * Correspondence: cenk.demiroglu@bilgi.edu.tr; Tel.: +90-21-2311-7848 \\ Academic Editor: Daniel Scott \\ Received: 31 January 2016; Accepted: 25 March 2016; Published: 6 April 2016
}

\begin{abstract}
Many ski resorts worldwide are going through deteriorating snow cover conditions due to anthropogenic warming trends. As the natural and the artificially supported, i.e., technical, snow reliability of ski resorts diminish, the industry approaches a deadlock. For this reason, impact assessment studies have become vital for understanding vulnerability of ski tourism. This study considers three resorts at one of the rapidly emerging ski destinations, Northeast Turkey, for snow reliability analyses. Initially one global circulation model is dynamically downscaled by using the regional climate model RegCM4.4 for 1971-2000 and 2021-2050 periods along the RCP4.5 greenhouse gas concentration pathway. Next, the projected climate outputs are converted into indicators of natural snow reliability, snowmaking capacity, and wind conditions. The results show an overall decline in the frequencies of naturally snow reliable days and snowmaking capacities between the two periods. Despite the decrease, only the lower altitudes of one ski resort would face the risk of losing natural snow reliability and snowmaking could still compensate for forming the base layer before the critical New Year's week. On the other hand, adverse high wind conditions improve as to reduce the number of lift closure days at all resorts. Overall, this particular region seems to be relatively resilient against climate change.
\end{abstract}

Keywords: climate change; RegCM4.4; snow reliability; snowmaking; ski tourism; Turkey

\section{Introduction}

The Intergovernmental Panel on Climate Change projects a global surface temperature rise of 0.3 to $4.8^{\circ} \mathrm{C}$ by the end of the 21st century, with respect to the 1986-2005 average [1], according to different pathways for increases in radiative forcing ranging within 2.6 to $8.5 \mathrm{~W} / \mathrm{m}^{2}$ by the end of the 21st century with respect to the pre-industrial 1850-1900 period [2]. Consequently, glacier losses and snow cover shrinkage are expected to continue [3]. At high-mountain regions, warming and its impacts are amplified even further due to various mechanisms [4]. Thus, ski tourism, as an industry dependent on snowy mountainous terrains, is claimed to be "the most directly and the most immediately affected" tourism type studied in a "methodologically and geographically diverse literature" [5,6]. 
The ski tourism industry yields 400 million visits annually and has become an essential component of socioeconomic development for certain regions such as the Alps and some recently emerging destinations such as China, Russia, and Turkey [7]. However, climate change remains to be a major threat to this impetus with the negative impacts already felt worldwide. In some of the past anomalously warm seasons, losses of skier visits up to $11 \%-12 \%$ were recorded in the US and the Alps [8,9]. In the US, it was found out that bad snowfall years resulted in losses of 15 million visits, US\$1 billion revenues, and 12,965 jobs during the 1999-2010 period [10]. Other econometric studies for various countries such as Japan [11], USA [12,13], Austria [14], Romania [15,16], Slovakia [17], and Australia [18] also confirm how observed changes in the ski tourism related climatic elements could lead to losses in business.

Besides understanding the past and the current situation of climate change impacts on ski tourism, many researchers focused on assessment studies on the future natural snow reliability of winter destinations. In doing so, most of these studies followed the "100-day rule", defined as a climatic threshold of minimum $30 \mathrm{~cm}$ deep and 100 days long snow cover duration that could help the financial viability of a ski resort [19], and other added indicators such as the ability to open during Christmas-New Year's holiday [20]. In Switzerland, pioneering studies [21,22] revealed that the number of naturally reliable ski areas could drop by as much as $71 \%$, depending on the degree of warming. Later in 2007, the OECD carried out an intra-regionally comparative study covering most of the larger ski areas of the Alps. Maximum dropouts of $79 \%, 52 \%, 76 \%, 63 \%$, and $97 \%$ were identified for Austria, Switzerland, Italy, France, and Germany; respectively, in terms of natural snow reliability under a $4{ }^{\circ} \mathrm{C}$ warming scenario [23]. In 2013, a study [24], which incorporated a snowmaking scenario, stressed out the underestimation of dropouts in the OECD study [23] for the Austrian case, and found the ratio of naturally non-snow-reliable areas as $92 \%$ by a statistical downscaling approach instead of the OECD's highly generalized empirical reference. Likewise, studies for North America also employed statistical downscaling techniques and examined selected sites in eastern Canada [20,25,26], northeastern USA [20,27-30], and California [31], with all results signaling decreases in snow reliability within the 21st century. In Oceania, an early study [32] for Australia claimed a complete loss of natural snow reliability for all resorts under a pessimistic scenario by the 2070s, even despite pulling the threshold to 60 days. Recent model projections for ski fields in Australia [33,34] and New Zealand $[34,35]$ also provide us with news on the shortening ski seasons, but as less of a threat for the latter, implying a possible spatial substitution of Australian skiers to their neighbors.

Climate change impacts on ski tourism has urged and driven the demand and supply actors towards adaptation in the forms of substitution behavior and technical, operational, and political measures [36]. Despite the variety of adaptation options, snowmaking has become the most common way to mitigate the negative impacts of climate change on snow cover and to recover snow reliability technically. In the Alps, snowmaking coverage on ski slopes has reached $48 \%$ in Switzerland [37], $65 \%$ in Austria [38], and almost 100\% in Italy [39]. Thus, most of the recent impact assessment studies have incorporated snowmaking modules in order to display the scenarios of recovery. In Austria, snowmaking has been proven to save 10 to $29 \%$ of the ski resorts from exit decisions according to warming scenarios of 1 to $4{ }^{\circ} \mathrm{C}$ [24]. In New Zealand, snowmaking is deemed to restore the 100 days season for all the resorts for the entire century [35].

Despite a growing body of literature on climate change and ski tourism $[5,6]$, there is still some underrepresentation of certain parts of the global domain [40]. For instance; there are only three studies [41-43] for the entire area of the Balkans, the Caucasus, and the Middle East, wherein lie more than 200 ski areas [44,45]. This study takes on a conjunctional section of this region-Turkey. The country is leading its way to become a global ski tourism destination as the authorities have recently announced a macro policy to establish 100 ski resorts, with 5000 hotels and 275,000 beds, worth $€ 49$ billion [46]. Among the areas with development priority, the inner Northeast is the most favored, where an Instrument for Pre-Accession by the EU has been allocated to develop a "winter tourism corridor" in the three provinces of the region [47]. The region's physical competence for ski 
tourism development is due to its mountainous terrain that covers $25,000 \mathrm{~km}^{2}$ above 2000 m.a.s.l. [48] and the dominant humid continental climate [49]. Currently, the region hosts two of the oldest and one of the newest ski resorts of the country. Snowmaking is available only at one of them whilst the other two have also placed it on their investment agendas. Changes to natural snow reliability and snowmaking capacities, as well as high wind conditions, of these three resorts are the foci of our study. Further details that distinguish resort characteristics such as specific location and vertical drop, etc., are not disclosed to maintain the privacy of these cases against any speculations that may arise from the results.

\section{Methods}

In this study, we aim at improving previous works [43,50-53] where snow reliability of ski resorts has been attempted to be examined through projections based on regional climate model outputs downscaled from various global circulation models (GCMs) for different greenhouse gas concentration pathways. It is thought that employment of dynamical, in addition to statistical, downscaling will portray a more realistic picture of climate change impacts on ski tourism domain, which is uncommon in the literature probably due to time and resource constraints. For the same reasons, we have limited our GCM and pathway selections as well as our timeframe.

The methodology has been comprised of two major parts, where initially the global circulation model, HadGEM2-ES of the Met Office Hadley Centre, has been dynamically downscaled to $10 \mathrm{~km}$ by using the regional climate model RegCM4.4 for the 1971-2000 control period and the 2021-2050 future period along the RCP4.5 greenhouse gas concentration pathway. Next, the projected outputs on snow water equivalent, near surface temperature and humidity have been converted into snow depth and wet bulb temperature values as indicators of ultimate natural snow reliability and snowmaking capacity. The maximum wind speed outputs have been treated for the assessment of lift closure days.

In the climate modeling part, we employed the fourth generation of a regional climate model, RegCM4.4, developed by the Abdus Salam International Centre for Theoretical Physics (ICTP) [54]. The RegCM is a regional climate model which was first developed in the late 1980s (RegCM1), and it has evolved to later versions in the 1990s (RegCM2 and 2.5), and the 2000s (RegCM3). The RegCM has been the first limited area model designed to be a public, open source, user friendly and portable code that can be applied to any region of the Earth.

Dickinson et al. [55] and Giorgi [56] originally suggested the idea that limited area models (LAMs) could be applied for regional studies. This idea includes one-way testing, meaning that high resolution Regional Climate Model (RCM) simulations are forced by General Circulation Model (GCM) outputs. Outputs of General Circulation Models provide initial and time-dependent meteorological lateral boundary conditions (LBCs) for regional climate models with no feedback from the RCM to the driving GCM-hence, one way. The dynamical structure of the first generation NCAR RegCM originated from the hydrostatic version of the National Center for Atmospheric Research (NCAR)-Pennsylvania State University (PSU) Mesoscale Model version 4 (MM4) in the late 1980s [55,57]. MM4 is a compressible, finite difference model with vertical s-coordinates. Later, an addition of the usage of a split-explicit time integration scheme with an algorithm to reduce horizontal diffusion in the presence of steep topographical gradients was made [58,59].

Consequently, the dynamical structure of the RegCM is similar to that of the hydrostatic version of Mesoscale Model version 5 (MM5) [60]. The RegCM4 is thus a hydrostatic, compressible, sigma-p vertical coordinate model. In hydrostatic models, vertical acceleration is negligible with respect to vertical pressure gradients and vertical buoyancy forces, a good approximation for synoptic and subsynoptic scales of motion. Therefore, hydrostatic models have been successfully applied with horizontal resolutions as small as about $10 \mathrm{~km}$. RegCM4 runs on an Arakawa B-grid that wind, and thermodynamical variables are horizontally staggered by using a timesplitting explicit integration scheme. In this scheme, the two fastest gravity modes are first apart from the model solution and then they are integrated with smaller time steps. For surface process representation, RegCM includes the 
sub-grid scaled version of biosphere-atmosphere transfer scheme (BATS) [61] as well as the community land model (CLM), version 3.5, as an option in its dynamical core for land surface processes $[62,63]$. Radiative transfer in RegCM4.4 has been modeled by using NCAR Community Climate Model, version CCM3 [64] radiation package. It has been modeled through the solar radiation transfer $\delta$-Eddington [64] approach. The part of the cloud radiation uses three parameters including the amount of cloudiness, cloud liquid water content and effective droplet radius. In the model, planetary boundary layer (PBL) scheme based on the non-local diffusion concept [65] is used. Convective rainfall patterns of the model are calculated by choosing one of the three schemes; modified-Kuo scheme [66,67], Grell scheme [68], and the MIT-Emanuel scheme [69,70]. This regional climate model system has been effectively applied to several domains, i.e., Europe, Central Asia, East Asia, South Asia, the Mediterranean, Africa, South America, North America, Central America, the Middle East, in various climate change studies [71-78] for the two decades.

In order to generate the historical and future outputs for the calculations of desired indicators, firstly HadGEM2-ES global climate model was dynamically downscaled to $50 \mathrm{~km}$ for the ski resort regions via RegCM4.4. Secondly, the RegCM4.4 was driven at a horizontal grid spacing of $10 \mathrm{~km}$ by applying double-nested method to the outputs of $50 \mathrm{~km}$ resolution simulations. All of the simulations were employed by using the Grell scheme with the Fritsch-Chappell type closure [79] and BATS1E parametrizations which represent the domain successfully. In this step of the modelling, the first run outputs, with $50 \mathrm{~km}$ resolutions, were employed as a forcing data to RegCM4.4. In other words, in order to represent the ski areas' climate more accurately, the RegCM4.4 was once again run with the previous model outputs, and thus all the regions were dynamically downscaled to $10 \mathrm{~km}$ resolution. The mid-range, RCP4.5, greenhouse gas concentration scenario outputs of the global model were used for future model forecasts to display a relatively optimistic pathway that stabilizes radiative forcing at $4.5 \mathrm{~W} / \mathrm{m}^{2}$ throughout the 21 st century.

The double nested downscaling of the GCM HadGEM2 by RegCM4.4 has provided us with daily outputs on snow water equivalent (SWE), maximum wind speed (SFCWINDMAX) and the three hourly outputs on near surface temperature (TAS) and near surface relative humidity (HURS) for the 1971-2000 reference period and the 2021-2050 period along the RCP4.5 pathway at the reference coordinates of the three ski resorts. The reference coordinates are based on grid corners and midpoints. Before running the simulations, in order to pinpoint the closest base coordinates of the ski resorts, several test runs were conducted by changing the central coordinates of the domain in the model's configuration file in deference to $10 \mathrm{~km}$-spaced grid size. Coordinates that fall within closest proximity to ski area bases were treated for analyses. Ultimately, the model was good enough to resolve the study region, where the topographic outputs deviated only $-376,-448$, and $-35 \mathrm{~m}$ from the original altitudes. Most deviations occurred at places with very steep slopes in close distances. Nonetheless, the modelled coordinates were still physiographically representative of the base areas in terms of elevation, differing only 164,2 , and $-35 \mathrm{~m}$ from the base stations. Moreover, we were able to correct the bias in the projected temperature values by adding the mean difference between historical model projections and observations stored at the Climatic Research Unit (CRU) dataset [80], by applying the delta-change correction technique, which is regarded as a robust method in correcting means based on observations [81], to the historical and the future outputs. The biases on the temperature variable were calculated as $2.26,0.7$, and $-0.1{ }^{\circ} \mathrm{C}$ for the Ski Resorts 1,2 , and 3; respectively.

Since the land-surface processes have been coupled to the RegCM4.4 via the Biosphere-Atmosphere Transfer Scheme [61], the SWE values for each assigned grid are computed considering numerous parameters such as land type, soil information, net surface heating, soil or snow heat capacity. Basically; snow cover $\left(S_{c v}\right)$, defined in snow water equivalent (SWE), is calculated by taking account of the rates of snow precipitation $\left(P_{S}\right)$, snowmelt $\left(S_{m}\right)$, and sublimation $\left(F_{q}\right)$ :

$$
\frac{\partial S_{c v}}{\partial t}=P_{s}-S_{m}-F_{q}
$$


Based on a count of the daily snow depth values, converted from SWE outputs through a reference snow density value of $265 \mathrm{~g} / \mathrm{cm}^{3}$ [82], we have applied the "100-days rule" of natural snow reliability for days with minimum snow depths of 30,50, and $70 \mathrm{~cm}$ for sufficient (NSR30), good (NSR50), and excellent (NSR70) conditions [18]; respectively.

Regarding snowmaking capacity, we have utilized the TAS and the HURS outputs in obtaining wet bulb temperatures according to Stull's formula [83];

$$
\begin{aligned}
W B T & =T A S \operatorname{atan}\left[0.151977(H U R S+8.313659)^{1 / 2}\right]+\operatorname{atan}(T A S+H U R S) \\
& -\operatorname{atan}(H U R S-1.676331)
\end{aligned}
$$

for which an hourly count has provided us with snow production conditions for which the maximum WBT threshold [84] is set at $-4{ }^{\circ} \mathrm{C}$ for assessment of the total capacity and the quality production is distinguished with a WBT value of $-7^{\circ} \mathrm{C}$ and below. For assessment of the base layer formation possibility during the critical pre- and early season months of November and December, the quality snowmaking potential is controlled for a desired production of 120 hours in total [85].

As a final step to our analyses, we have made use of the SFCWINDMAX output and checked the days where the top wind speed exceeds $50 \mathrm{~km} / \mathrm{h}$ (W50+). Such condition provides us with information on the suspension of chairlift and gondola operations with reference to risk limits in common practice.

\section{Results}

An average temperature change of $+2.15{ }^{\circ} \mathrm{C}$ is expected at the reference points of the three ski resorts in Northeast Turkey in the 2021-2050 period, according to the RCP4.5 scenario and with respect to the 1971-2000 normal (Table 1). Warming during the ski season (NDJFMA) is below the annual average, except for at Ski Resort 2. Within the ski season, much of the warming takes place in the late winter and the later spring, whereas the least warming is projected for December, when the critical snow accumulation and/or production has to be realized before the popular New Year's week.

Table 1. Projected Temperature $\left({ }^{\circ} \mathrm{C}\right)$ Changes at the Major Ski Resorts in Northeast Turkey from 1971-2000 to 2021-2050 according to the RCP4.5 Scenario.

\begin{tabular}{ccccccccc}
\hline \multirow{2}{*}{$\begin{array}{c}\text { Ski } \\
\text { Resort }\end{array}$} & \multicolumn{8}{c}{ Period } \\
\cline { 2 - 9 } & November & December & January & February & March & April & Seasonal & Annual \\
\hline 1 & 1.85 & 1.21 & 1.78 & 2.38 & 1.68 & 3.21 & 2.02 & 2.17 \\
2 & 1.95 & 1.29 & 1.69 & 2.33 & 1.63 & 2.98 & 2.21 & 2.13 \\
3 & 2.04 & 1.25 & 1.61 & 2.29 & 1.61 & 2.92 & 1.96 & 2.15 \\
\hline
\end{tabular}

Regarding the changes on the snow cover durations at certain depths, an overall decline is projected for the reference altitudes of the ski resorts towards the end of the first half of the century (Table 2). Despite the decrease, only one ski resort faces the risk of losing its absolute natural snow reliability based on minimal snow depth requirements (NSR30). Generally, magnitude of the negative change in the frequency of naturally snow reliable days increases as the threshold for snow depth conditions is set higher at 50 and $70 \mathrm{~cm}$.

Table 2. Projected Changes for Natural Snow Reliability at the Major Ski Resorts in Northeast Turkey according to the RCP4.5 Scenario.

\begin{tabular}{cccccccccc}
\hline \multirow{2}{*}{$\begin{array}{c}\text { Ski } \\
\text { Resort }\end{array}$} & \multicolumn{3}{c}{ NSR30 } & \multicolumn{3}{c}{ NSR50 } & \multicolumn{2}{c}{ NSR70 } \\
\cline { 2 - 10 } & $\mathbf{1 9 7 1 - 2 0 0 0}$ & $\mathbf{2 0 2 1 - 2 0 5 0}$ & Change & 1971-2000 & 2021-2050 & Change & 1971-2000 & 2021-2050 Change \\
\hline 1 & 107 & 87 & $-19 \%$ & 90 & 64 & $-29 \%$ & 73 & 49 & $-33 \%$ \\
2 & 126 & 105 & $-17 \%$ & 104 & 84 & $-19 \%$ & 85 & 66 & $-22 \%$ \\
3 & 132 & 114 & $-14 \%$ & 113 & 91 & $-19 \%$ & 93 & 70 & $-25 \%$ \\
\hline
\end{tabular}


As with natural snow reliability, an overall decline is projected also for snowmaking capacities of the three resorts (Table 3). In terms of total snowmaking and quality snowmaking, the declining trend is the strongest at Ski Resort 1. Regarding base layer formation, all resorts lose their capacities by $25 \%$ to $30 \%$, whilst Ski Resort 1 falls below the desired 120 production hours limit. Therefore, some natural snow cover formation is essential for this resort to support the base layer formation before the critical New Year's week. However, we should also note that this ski resort has a very high ski area vertical drop, making its sensitivity very relative to the chosen altitude references for assessment. In this study, the reference coordinates were located at the lower half of the ski area, close to the base station. It is likely that the snowmaking capacity would improve further with generally colder air in the higher terrains, except during temperature inversion phenomena.

Table 3. Projected Changes for Annual Snowmaking Capacities (hours) at the Major Ski Resorts in Northeast Turkey according to the RCP4.5 Scenario.

\begin{tabular}{cccccccccc}
\hline \multirow{2}{*}{$\begin{array}{c}\text { Ski } \\
\text { Resort }\end{array}$} & \multicolumn{2}{c}{ Total Snowmaking } & \multicolumn{2}{c}{ Quality Snowmaking } & \multicolumn{2}{c}{ Early Snowmaking } \\
\cline { 2 - 9 } & 1971-2000 & $\mathbf{2 0 2 1 - 2 0 5 0}$ & Change & 1971-2000 & 2021-2050 & Change & 1971-2000 & 2021-2050 Change \\
\hline 1 & 1265 & 902 & $-29 \%$ & 636 & 414 & $-35 \%$ & 133 & 94 & $-29 \%$ \\
2 & 2237 & 1830 & $-18 \%$ & 1338 & 993 & $-26 \%$ & 344 & 259 & $-25 \%$ \\
3 & 2472 & 2057 & $-17 \%$ & 1508 & 1134 & $-25 \%$ & 426 & 298 & $-30 \%$ \\
\hline
\end{tabular}

Last but not the least, we looked into the change with the frequency of high winds that could jeopardize aerial cable lift rides and lead to closure of ski areas. Apparently, the number of possible closure days will be reduced by $29 \%$ to $50 \%$ (Table 4 ). Yet, it should be noted that these results are representative of the lower ski areas and a generalization could be misleading, especially since the strongest winds are likely to occur close to the summits in mountainous areas.

Table 4. Projected Changes for Annual Lift Closure Days at the Major Ski Resorts in Northeast Turkey according to the RCP4.5 Scenario.

\begin{tabular}{cccc}
\hline \multirow{2}{*}{ Ski Resort } & \multicolumn{3}{c}{ W50+ } \\
\cline { 2 - 4 } & $\mathbf{1 9 7 1 - 2 0 0 0}$ & $\mathbf{2 0 2 1 - 2 0 5 0}$ & Change \\
\hline 1 & 6.4 & 3.5 & $-45 \%$ \\
2 & 0.8 & 0.4 & $-50 \%$ \\
3 & 2.4 & 1.7 & $-29 \%$ \\
\hline
\end{tabular}

\section{Discussion}

One of the few studies for the wider region of our study domain identified Northeast Turkey, together with the Western Caucasus, as having constantly enjoyed cold early winters suitable for skiing, based on comparative analyses of decades long meteorological observations at the nearest station, as opposed to the troubled sites in the Alps and East Asia [42]. Our results do not conform to a continuation of the discovered past linear trend of decreasing air temperature in December, but confirm that the study domain would be exposed to a minimal warming for the season start. Moreover, a preliminary study [86] at one of the domain resorts has found out that the financial breakeven for the establishments could be as low as 68 days, therefore; flexing down the natural snow reliability threshold of 100 days, as in the case with Australia [32], would imply an even larger resilience. Yet, we should also note that this study was administered in the light of the RCP4.5 scenario, which is rather optimistic, albeit almost divergent until the 2030s, when compared to the RCP8.5 pathway, which is commonly referred to as the "business as usual" scenario [2].

Besides natural snow reliability, snow production potential is also strong for the resorts of Northeast Turkey, with an early season snowmaking capacity that will fully be available for at least 
two of the resorts until 2050. However, unlike in many other destinations [37-39], snowmaking is still uncommon in Turkey, gaining popularity only recently. One resort of our domain was the first to have purchased a system in 1998, but its initial utilization was only felt necessary in late 2008 due to a delay of skiable natural snowpack for more than a month. Today, the resort is partially equipped with snowmaking, due to fragmented operational ownership, still making it one of the first destinations to start the season at the earliest.

Snowmaking, however, comes along with its costs and consequences [39,87-89]. Increasing energy burdens and costs and competition for common water resources, which are expected to get scarcer with climate change, are the top two concerns. In Germany, it is calculated that water consumption would double by 2050 should the ski tourism industry be permitted for snowmaking for climate change adaptation in an open competition environment [90]. In the USA, additional energy consumption by snowmaking was found out to be $31 \%$ to $37 \%$ during the anomalously warm 1998-1999 and the 2001-2002 seasons [8]. Moreover, any energy supply by fossil fuels means contribution to GHG emissions, thus; global warming. Consumers, on the other hand, have different responses to artificially made snow [91-93]. In Turkey, a recent study found that preference of tourists for artificially made snow was "low" to "medium", while skiing for professional training did show some positive correlation with higher preference levels [94]. Last but not the least; snowmaking is based on a technology which itself is also limited by climatic factors that require relatively cold and dry weather conditions, making it as another system sensitive to climate change. A study [51] showed that the high quality snowmaking capacity on the current slopes of a major ski resort in Northwest Turkey is to be terminated in the near future. Such developments could lead to a more solid genesis of "winners" and "losers" in the Turkish ski tourism market, as changing snow reliability of the conventional resorts could lead to spatial substitution. This is also true at the international level, as a part of the Alpine market would also continue looking for more snow reliable ski resorts in the future, but, in that case, Northeast Turkey would not be alone and have to compete with other relatively reliable destinations such as the Western Caucasus [42] and Bulgaria [43].

It should be noted that this study had some limitations in terms of its methodological application and geographical coverage. First of all, model validation and consequent bias correction efforts were only possible for the temperature variable as our referral dataset could not provide any observations for the snow-water equivalent and the relative humidity variables. This drawback could be eliminated in the future with observational inputs from the meteorological stations founded at the ski resort sites a couple of years ago. Study domain, on the other hand, could also be expanded in the future, once the forthcoming non-hydrostatic version of the RegCM provides us with dynamical downscaling at resolutions as high as $1 \mathrm{~km}$, minimizing topographic deviations.

\section{Conclusions}

In Turkey, it might be too early to talk about climate change winners and losers in terms of ski tourism supply, as the country is still at the start of utilizing its mountains and developing ski tourism further into international standards. However, those in the high altitude, inner Northeast present a relatively sound resilience. Therefore, they could make use of this advantage for competition against their western counterparts, bearing in mind that competitiveness also requires good facilities, management and accessibility.

Hereby, we have managed to contribute to the previous works by usage of a complex methodology that employs dynamical, instead of just statistical, downscaling. As time and resources permit, different GCMs and pathways could be forced into the RegCM in order to get a more diverse picture of forthcoming impacts. Ultimately, hybridification of the next generation RegCM into the state-of-the-art methods such as agent based models (ABMs) could be utilized for a better understanding of the interactions among climate change and ski tourism supply and demand in a wider domain that extends within and outside Turkey. 
Acknowledgments: This research has been supported by Boğaziçi University Research Fund Grant Number 10421. Corresponding author was 2014-2015 Mercator-IPC Fellow of the Istanbul Policy Center-Sabanc1 University-Stiftung Mercator Initiative.

Author Contributions: Osman Cenk Demiroglu prepared the introductory review and elaborated on the results. All authors contributed equally to the methodological design. Mustafa Tufan Turp, Tugba Ozturk, and Mehmet Levent Kurnaz realized climate modelling, and Osman Cenk Demiroglu and Mehmet Tufan Turp worked on converting the model outputs into snow reliability and snowmaking indicators.

Conflicts of Interest: The authors declare no conflict of interest.

\section{References}

1. Hartmann, D.L.; Klein Tank, A.M.G.; Rusticucci, M.; Alexander, L.V.; Brönnimann, S.; Charabi, Y.; Dentener, F.J.; Dlugokencky, E.J.; Easterling, D.R.; Kaplan, A.; et al. Observations: Atmosphere and surface. In Climate Change 2013: The Physical Science Basis. Contribution of Working Group I to the Fifth Assessment Report of the Intergovernmental Panel on Climate Change; Stocker, T.F., Qin, D., Plattner, G.-K., Tignor, M., Allen, S.K., Boschung, J., Nauels, A., Xia, Y., Bex, V., Midgley, P.M., Eds.; Cambridge University Press: Cambridge, UK; New York, NY, USA, 2013; pp. 159-254.

2. Van Vuuren, D.P.; Edmonds, J.; Kainuma, M.; Riahi, K.; Thomson, A.; Hibbard, K.; Hurtt, G.C.; Kram, T.; Krey, V.; Lamarque, J.F.; et al. The representative concentration pathways: An overview. Clim. Chang. 2011, 109, 5-31. [CrossRef]

3. Kirtman, B.; Power, S.B.; Adedoyin, J.A.; Boer, G.J.; Bojariu, R.; Camilloni, I.; Doblas-Reyes, F.J.; Fiore, A.M.; Kimoto, M.; Meehl, G.A.; et al. Near-term climate change: Projections and predictability. In Climate Change 2013: The Physical Science Basis. Contribution of Working Group I to the Fifth Assessment Report of the Intergovernmental Panel on Climate Change; Stocker, T.F., Qin, D., Plattner, G.-K., Tignor, M., Allen, S.K., Boschung, J., Nauels, A., Xia, Y., Bex, V., Midgley, P.M., Eds.; Cambridge University Press: Cambridge, UK; New York, NY, USA, 2013; pp. 953-1028.

4. Pepin, N.; Bradley, R.S.; Diaz, H.F.; Baraer, M.; Caceres, E.B.; Forsythe, N.; Fowler, H.; Greenwood, G.; Hashmi, M.Z.; Liu, X.D.; et al. Elevation-dependent warming in mountain regions of the world. Nat. Clim. Chang. 2015, 5, 424-430. [CrossRef]

5. Scott, D.; Hall, C.M.; Gössling, S. Tourism and Climate Change: Impacts, Adaptation and Mitigation; Routledge: London, UK, 2012.

6. Demiroglu, O.C.; Dannevig, H.; Aall, C. The multidisciplinary literature of ski tourism and climate change. In Tourism Research: An Interdisciplinary Perspective; Kozak, M., Kozak, N., Eds.; Cambridge Scholars Publishing: Cambridge, UK, 2013; pp. 223-237.

7. 2015 International Report on Snow \& Mountain Tourism-Overview of the Key Industry Figures for Ski Resorts. Available online: http:/ /www.vanat.ch/RM-world-report-2015.pdf (accessed on 31 January 2016).

8. Dawson, J.; Scott, D.; McBoyle, G. Climate change analogue analysis of ski tourism in northeastern USA. Clim. Res. 2009, 39, 1-9. [CrossRef]

9. Steiger, R. The impact of snow scarcity on ski tourism: An analysis of the record warm season 2006/2007 in Tyrol (Austria). Tour. Rev. 2011, 66, 4-13. [CrossRef]

10. Burakowski, E.; Magnusson, M. Climate Impacts on the Winter Tourism Economy in the United States; Natural Resources Defense Council: New York, NY, USA, 2012.

11. Fukushima, T.; Kureha, M.; Ozaki, N.; Fujimori, Y.; Harasawa, H. Influences of air temperature change on leisure industries: Case study on ski activities. Mitig. Adapt. Strateg. Clim. Chang. 2003, 7, 173-189. [CrossRef]

12. Hamilton, L.C.; Brown, B.C.; Keim, B. Ski areas, weather and climate: Time series models for integrated research. Int. J. Climatol. 2007, 27, 2113-2124. [CrossRef]

13. Shih, C.; Nicholls, S.; Holecek, D.F. Impact of weather on downhill ski lift ticket sales. J. Travel Res. 2009, 47, 359-372. [CrossRef]

14. Falk, M. Impact of long-term weather on domestic and foreign winter tourism demand. Int. J. Tour. Res. 2011, 15, 1-17. [CrossRef]

15. Surugiu, C.; Dincă, A.I.; Micu, D. Tourism destinations vulnerable to climate changes: An econometric approach on Predeal Resort. Bul. Univ. Pet. Gaze Ploieşti 2010, 62, 111-120. 
16. Surugiu, C.; Surugiu, M.-R.; Frent, C.; Breda, Z. Effects of climate change on Romanian mountain tourism: Are they positive or mostly negative? Eur. J. Tour. Hosp. Recreat. 2011, 2, 42-71.

17. Demiroglu, O.C.; Kucerova, J.; Ozcelebi, O. Snow reliability and climate elasticity: Case of a Slovak ski resort. Tour. Rev. 2015, 70, 1-12. [CrossRef]

18. Pickering, C.M. Changes in demand for tourism with climate change: A case study of visitation patterns to six ski resorts in Australia. J. Sustain. Tour. 2011, 19, 767-781. [CrossRef]

19. Witmer, W. Erfassung, Bearbeitung und Kartierung von Schneedaten in der Schweiz; Geographisches Institut der Universität Bern: Bern, Switzerland, 1986.

20. Scott, D.; McBoyle, G.; Minogue, A.; Mills, B. Climate change and the sustainability of ski-based tourism in eastern North America: A reassessment. J. Sustain. Tour. 2006, 14, 376-398. [CrossRef]

21. König, U.; Abegg, B. Impacts of climate change on winter tourism in the Swiss Alps. J. Sustain. Tour. 1997, 5, 46-58. [CrossRef]

22. Elsasser, H.; Messerli, P. The Vulnerability of the Snow Industry in the Swiss Alps. J. Mt. Res. Dev. 2001, 21, 335-339. [CrossRef]

23. Abegg, B.; Agrawala, S.; Crick, F.; de Montfalcon, A. Climate change impacts and adaptation in winter tourism. In Climate Change in the European Alps: Adapting Winter Tourism and Natural Hazards Management; Agrawala, S., Ed.; OECD: Paris, France, 2007; pp. 25-60.

24. Steiger, R.; Abegg, B. The sensitivity of Austrian ski areas to climate change. Tour. Plan. Dev. 2013, 10, 480-493. [CrossRef]

25. Scott, D.; McBoyle, G.; Mills, B. Climate change and the skiing industry in Southern Ontario (Canada): Exploring the importance of snowmaking as a technical adaptation. Clim. Res. 2003, 23, 171-181. [CrossRef]

26. Scott, D.; McBoyle, G.; Minogue, A. Climate change and Quebec's ski industry. Glob. Environ. Chang. 2007, 17, 181-190. [CrossRef]

27. Dawson, J.; Scott, D. Climate change vulnerability in the Vermont ski tourism sector. Ann. Leis. Res. 2007, 10, 550-571. [CrossRef]

28. Scott, D.; Dawson, J.; Jones, B. Climate change vulnerability of the US Northeast winter recreation-tourism sector. Mitig. Adapt. Strateg. Glob. Chang. 2008, 13, 577-596. [CrossRef]

29. Dawson, J.; Scott, D. Systems analysis of climate change vulnerability for the US Northeast ski sector. Tour. Hosp. Plan. Dev. 2010, 7, 219-235. [CrossRef]

30. Dawson, J.; Scott, D. Managing for climate change in the alpine ski sector. Tour. Manag. 2013, 35, $244-254$. [CrossRef]

31. Hayhoe, K.; Cayan, D.; Field, C.B.; Frumhoff, P.C.; Maurer, E.P.; Miller, N.L.; Moser, S.C.; Schneider, S.H.; Cahill, K.N.; Cleland, E.E.; et al. Emissions pathways, climate change, and impacts on California-Supporting text. PNAS 2004, 101, 12422-12427. [CrossRef] [PubMed]

32. König, U. Tourism in a Warmer World: Implications of Climate Change Due to Enhanced Greenhouse Effect for the Ski Industry in the Australian Alps; University of Zürich: Zürich, Switzerland, 1998.

33. Hennessy, K.J.; Whetton, P.H.; Walsh, K.; Smith, I.N.; Bathols, J.M.; Hutchinson, M.; Sharples, J. Climate change effects on snow conditions in mainland Australia and adaptation at ski resorts through snowmaking. Clim. Res. 2008, 35, 255-270. [CrossRef]

34. Hendrikx, J.; Zammit, C.; Hreinsson, E.Ö.; Becken, S. A comparative assessment of the potential impact of climate change on the ski industry in New Zealand and Australia. Clim. Chang. 2013, 19, 965-978. [CrossRef]

35. Hendrikx, J.; Hreinsson, E.Ö. The potential impact of climate change on seasonal snow in New Zealand: Part II-Industry vulnerability and future snowmaking potential. Theor. Appl. Climatol. 2012, 110, 619-630. [CrossRef]

36. Scott, D.; McBoyle, D. Climate change adaptation in the ski industry. Mitig. Adapt. Strateg. Glob. Chang. 2007, 12, 1411-1431. [CrossRef]

37. Fakten \& Zahlen zur Schweizer Seilbahnbranche: Ausgabe 2015. Available online: http://www.seilbahnen.org/ de/Branche/Fakten-Zahlen/Fakten-Zahlen (accessed on 23 February 2016).

38. FACTSHEET-Beschneiung in Österreich. Available online: https://www.wko.at/Content.Node/branchen/ oe/TransportVerkehr/Seilbahnen/Factsheet-Beschneiung_2.pdf (accessed on 23 February 2016).

39. Rixen, C.; Teich, M.; Lardelli, C.; Gallati, D.; Pohl, M.; Pütz, M.; Bebi, P. Winter tourism and climate change in the Alps: An assessment of resource consumption, snow reliability, and future snowmaking potential. Mt. Res. Dev. 2011, 31, 229-236. [CrossRef] 
40. SkiKlima: A Geo-Bibliography of Climate Change and Ski Tourism Research. Available online: http:/ /www.skiklima.com (accessed on 31 January 2016).

41. Mochurova, M.; Kaloyanov, T.; Mishev, P. Impacts of climate change on winter tourism in Borovets. Econ. Stud. 2010, 2, 98-126.

42. Pestereva, N.; Popova, N.Y.; Shagarov, L.M. Modern climate change and mountain skiing tourism: The Alps and the Caucasus. Eur. Res. 2012, 30, 1602-1617.

43. Demiroglu, O.C.; Turp, M.T.; Ozturk, T.; An, N.; Kurnaz, M.L. Technical climate change adaptation options of the major ski resorts in Bulgaria. In Sustainable Mountain Regions: Challenges and Perspectives in Southeastern Europe; Koulov, B., Zhelezov, G., Eds.; Springer: Basel, Switzerland, 2016; pp. 77-88.

44. Ski Resorts-Skiing-Ski Worldwide. Available online: http://www.skiresort.info (accessed on 31 January 2016).

45. Turkish Ski Resorts. Available online: http://www.kayakharitasi.com (accessed on 31 January 2016).

46. Hudson, S.; Hudson, L. Winter Sports Tourism: Working in Winter Wonderlands; Goodfellow: Oxford, UK, 2015.

47. TR-Ankara: IPA-Technical Assistance for Development of A Winter Tourism Corridor in Erzurum, Erzincan and Kars. Available online: https://ipa.sanayi.gov.tr/Files/Attachments/OtherFiles/forecast11092012163046.PDF (accessed on 31 January 2016).

48. Elibüyük, M.; Yılmaz, E. Altitude steps and slope groups of Turkey in comparison with geographical regions and sub-regions. Coğrafi Bilim. Derg. 2010, 8, 27-55.

49. World Maps of Köppen-Geiger Climate Classification. Available online: http://koeppen-geiger.vu-wien.ac.at/ present.htm (accessed on 31 January 2016).

50. Ceber, Z.P.; Ozturk, T.; Kurnaz, M.L. Impacts of climate change on winter tourism in Turkey. In Proceedings of the International Conference: Sustainability Issues and Challenges in Tourism, Istanbul, Turkey, 3-5 October 2013.

51. Ozturk, T.; Demiroglu, O.C.; Turp, M.T.; Türkeş, M.; Kurnaz, M.L. Projections for changes in natural and technical snow reliability of a major Turkish ski resort by using RegCM4.3.5. In Proceedings of the European Geosciences Union General Assembly, Vienna, Austria, 27 April-2 May 2014.

52. Ozturk, T.; Demiroglu, O.C.; Turp, M.T.; Türkeş, M.; Kurnaz, M.L.; An, N. RegCM4.3.5 Projections for changes in technical snow reliability of a major Norwegian ski resort. In Proceedings of the International Adventure Conference, Sogndal, Norway, 24-26 November 2014.

53. Demiroglu, O.C.; Ozturk, T.; Turp, M.T.; Kurnaz, M.L. A refined methodology for modelling climate change impacts on snow sports tourism. In Proceedings of the European Geosciences Union General Assembly, Vienna, Austria, 12-17 April 2015.

54. Pal, J.S.; Giorgi, F.; Bi, X.; Elguindi, N.; Solmon, F.; Rauscher, S.A.; Gao, X.; Francisco, R.; Zakey, A.; Winter, J.; et al. Regional climate modeling for the developing world: The ICTP RegCM3 and RegCNET. Bull. Am. Meteorol. Soc. 2007, 88, 1395-1409. [CrossRef]

55. Dickinson, R.E.; Errico, R.M.; Giorgi, F.; Bates, G.T. A regional climate model for western United States. Clim. Chang. 1989, 15, 383-422. [CrossRef]

56. Giorgi, F. Simulation of regional climate using a limited area model nested in a general circulation model. J. Clim. 1990, 3, 941-963. [CrossRef]

57. Giorgi, F. Two-dimensional simulations of possible meso-scale effects of nuclear war fires: 1 . model description. J. Geophys. Res. 1989, 94, 1127-1144. [CrossRef]

58. Giorgi, F.; Marinucci, M.R.; Bates, G.T. Development of a second generation regional climate model (RegCM2) I: Boundary layer and radiative transfer processes. Mon. Weather Rev. 1993, 121, 2794-2813. [CrossRef]

59. Giorgi, F.; Bates, G.T.; Nieman, S.J. The Multi-year surface climatology of a regional atmospheric model over the western United States. J. Clim. 1993, 6, 75-95. [CrossRef]

60. Grell, G.A.; Dudhia, J.; Stauffer, D.R. A Description of the Fifth-Generation Penn State/NCAR Mesoscale Model (MM5); National Center for Atmospheric Research: Boulder, CO, USA, 1994.

61. Dickinson, R.E.; Kennedy, P.J.; Henderson-Sellers, A. Biosphere-Atmosphere Transfer Scheme (BATS) Version 1e as Coupled to the NCAR Community Climate Model; National Center for Atmospheric Research: Boulder, CO, USA, 1993.

62. Oleson, K.W.; Niu, G.Y.; Yang, Z.L.; Lawrence, D.M.; Thornton, P.E.; Lawrence, P.J.; Stöckli, R.; Dickinson, R.E.; Bonan, G.B.; Levis, S.; et al. Improvements to the community land model and their impact on the hydrological cycle. J. Geophys. Res. Biogeosci. 2008, 113, G1. [CrossRef] 
63. Tawfik, A.B.; Steiner, A.L. The role of soil ice in land-atmosphere coupling over the United States: A soil moisture-precipitation winter feedback mechanism. J. Geophys. Res. Atmos. 2011, 116, D2. [CrossRef]

64. Kiehl, J.T.; Hack, J.J.; Bonan, G.B.; Boville, B.A.; Briegleb, B.P.; Williamson, D.L.; Rasch, P.J. Description of the NCAR Community Climate Model (CCM3); National Center for Atmospheric Research: Boulder, CO, USA, 1996.

65. Holtslag, A.A.M.; de Bruijn, E.I.F.; Pan, H.L. A high resolution air mass transformation model for short-range weather forecasting. Mon. Weather Rev. 1990, 118, 1561-1575. [CrossRef]

66. Anthes, R.A. A cumulus parameterization scheme utilizing a one-dimensional cloud model. Mon. Weather Rev. 1977, 105, 270-286. [CrossRef]

67. Anthes, R.A.; Hsie, E.Y.; Kuo, Y.H. Description of the Penn State/NCAR Mesoscale Model Version 4 (MM4); National Center for Atmospheric Research: Boulder, CO, USA, 1987.

68. Grell, G.A. Prognostic evaluation of assumptions used by cumulus parameterizations. Mon. Weather Rev. 1993, 121, 764-787. [CrossRef]

69. Emanuel, K.A. A scheme for representing cumulus convection in large-scale models. J. Atmos. Sci. 1991, 48, 2313-2329. [CrossRef]

70. Emanuel, K.A.; Živkovic-Rothman, M. Development and evaluation of a convection scheme for use in climate models. J. Atmos. Sci. 1999, 56, 1766-1782. [CrossRef]

71. Chen, M.; Pollard, D.; Barron, E.J. Comparison of future climate change over North America simulated by two regional models. J. Geophys. Res. Atmos. 2003, 108, D12. [CrossRef]

72. Coppola, E.; Giorgi, F.; Raffaele, F.; Fuentes-Franco, R.; Giuliani, G.; Llopart-Pereira, M.; Mamgain, A.; Mariotti, L.; Diro, G.T.; Torma, C. Present and future climatologies in the phase I CREMA experiment. Clim. Chang. 2014, 125, 23-38. [CrossRef]

73. Gao, X.; Giorgi, F. Increased aridity in the Mediterranean region under greenhouse gas forcing estimated from high resolution simulations with a regional climate model. Glob. Planet. Chang. 2008, 62, 195-209. [CrossRef]

74. Giorgi, F.; Bi, X.; Pal, J.S. Mean interannual variability and trends in a regional climate change experiment over Europe. I. Present-day climate (1961-1990). Clim. Dyn. 2004, 22, 733-756. [CrossRef]

75. Giorgi, F.; Bi, X.; Pal, J. Mean interannual variability and trends in a regional climate change experiment over Europe. II: Climate change scenarios (2071-2100). Clim. Dyn. 2004, 23, 839-858. [CrossRef]

76. Giorgi, F.; Coppola, E.; Solmon, F.; Mariotti, L.; Sylla, M.B.; Bi, X.; Elguindi, N.; Diro, G.T.; Nair, V.; Giuliani, G.; et al. RegCM4: Model description and preliminary tests over multiple CORDEX domains. Clim. Res. 2012, 52, 7-29. [CrossRef]

77. Ozturk, T.; Altinsoy, H.; Türkeş, M.; Kurnaz, M.L. Simulation of temperature and precipitation climatology for the Central Asia CORDEX domain using RegCM4.0. Clim. Res. 2012, 51, 63-76. [CrossRef]

78. Turp, M.T.; Ozturk, T.; Türkeş, M.; Kurnaz, M.L. Investigation of projected changes for near future air temperature and precipitation climatology of Turkey and surrounding regions by using the regional climate model RegCM4.3.5. Aegean Geogr. J. 2014, 23, 1-24.

79. Fritsch, J.M.; Chappell, C.F. Numerical prediction of convectively driven mesoscale pressure systems. Part I: Convective parameterization. J. Atmos. Sci. 1980, 37, 1722-1733. [CrossRef]

80. Mitchell, T.D.; Carter, T.R.; Jones, P.D.; Hulme, M.; New, M. A Comprehensive Set of High-Resolution Grids of Monthly Climate for Europe and the Globe: The Observed Record (1901-2000) and 16 Scenarios (2001-2100); Tyndall Centre: Norwich, UK, 2004.

81. Teutschbein, C.; Seibert, J. Is bias correction of regional climate model (RCM) simulations possible for non-stationary conditions? Hydrol. Earth Syst. Sci. 2013, 17, 5061-5077. [CrossRef]

82. Sorman, U.S.; Beser, O. Determination of snow water equivalent over the eastern part of Turkey using passive microwave data. Hydrol. Process. 2013, 27, 1945-1958. [CrossRef]

83. Stull, R. Wet-bulb temperature from relative humidity and air temperature. J. Appl. Meteorol. Climatol. 2011, 50, 2267-2269. [CrossRef]

84. Wet-Bulb Chart Celsius. Available online: https://www.snowathome.com/pdf/wet_bulb_chart_celsius.pdf (accessed on 31 January 2016).

85. Steiger, R.; Mayer, M. Snowmaking and climate change. Mt. Res. Dev. 2008, 28, 292-298. [CrossRef]

86. Demiroglu, O.C.; An, N. Questioning Witmer's 100 days rule for snow reliability analyses. In Proceedings of the 4th International Conference on Climate, Tourism and Recreation, Istanbul, Turkey, 17-19 September 2015. 
87. Rixen, C.; Stoeckli, V.; Ammann, W. Does artificial snow production affect soil and vegetation of ski pistes? A review. Perspect. Plant Ecol. Evol. Syst. 2003, 5, 219-230. [CrossRef]

88. Pickering, C.M.; Buckley, R. Climate response by ski resorts: The shortcomings of snowmaking. Ambio 2010, 39, 430-438. [CrossRef] [PubMed]

89. Damm, A.; Köberl, J.; Töglhofer, C. Economic impacts of climate change on winter tourism: Challenges for ski area operators. In Proceedings of the European Geosciences Union General Assembly, Vienna, Austria, 22-27 April 2012.

90. Soboll, A.; Schmude, J. Simulating tourism water consumption under climate change conditions using agent-based modelling: The example of ski areas. Ann. Assoc. Am. Geogr. 2011, 101, 1049-1066. [CrossRef]

91. Pickering, C.M.; Castley, J.G.; Burtt, M. Skiing less often in a warmer world: Attitudes of tourists to climate change in an Australian ski resort. Geogr. Res. 2010, 48, 137-147. [CrossRef]

92. Pütz, M.; Gallati, D.; Kytzia, S.; Elsasser, H.; Lardelli, C.; Teich, M.; Waltert, F.; Rixen, C. Winter tourism, climate change, and snowmaking in the Swiss Alps: Tourists' attitudes and regional economic impacts. Mt. Res. Dev. 2011, 31, 357-362. [CrossRef]

93. Hopkins, D.; Higham, J.E.S.; Becken, S. Climate change in a regional context: Relative vulnerability in the Australasian skier market. Reg. Environ. Chang. 2013, 13, 449-458. [CrossRef]

94. Demiroglu, O.C. An empirical study on the climate change perception and adaptation of winter sports tourists in Turkey. In Proceedings of the Ulusal Alternatif Turizm Kongresi, Erzincan, Turkey, 7-9 April 2016.

(C) 2016 by the authors; licensee MDPI, Basel, Switzerland. This article is an open access article distributed under the terms and conditions of the Creative Commons by Attribution (CC-BY) license (http:/ / creativecommons.org/licenses/by/4.0/). 